Gibson, T.M., et al., 2021, A detrital zircon test of large-scale terrane displacement along the Arctic margin of North America: Geology, v. 49, https://doi.org/10.1130/G48336.1

\title{
A detrital zircon test of large-scale terrane displacement along the Arctic margin of North America
}

Timothy M. Gibson, Karol Faehnrich, James F. Busch, William C. McClelland, Mark D. Schmitz, and Justin V. Strauss

\section{SUPPLEMENTAL METHODS}

\section{Data Compilation}

Detrital zircon U-Pb data were compiled from previously published samples of TonianCambrian strata from the North Slope subterrane and northwestern Laurentian autochthon (i.e., Yukon block and Mackenzie platform), as well as newly reported samples of Tonian-Cambrian strata from the Yukon block presented herein (see below; Fig. S1; Tables S1-3).

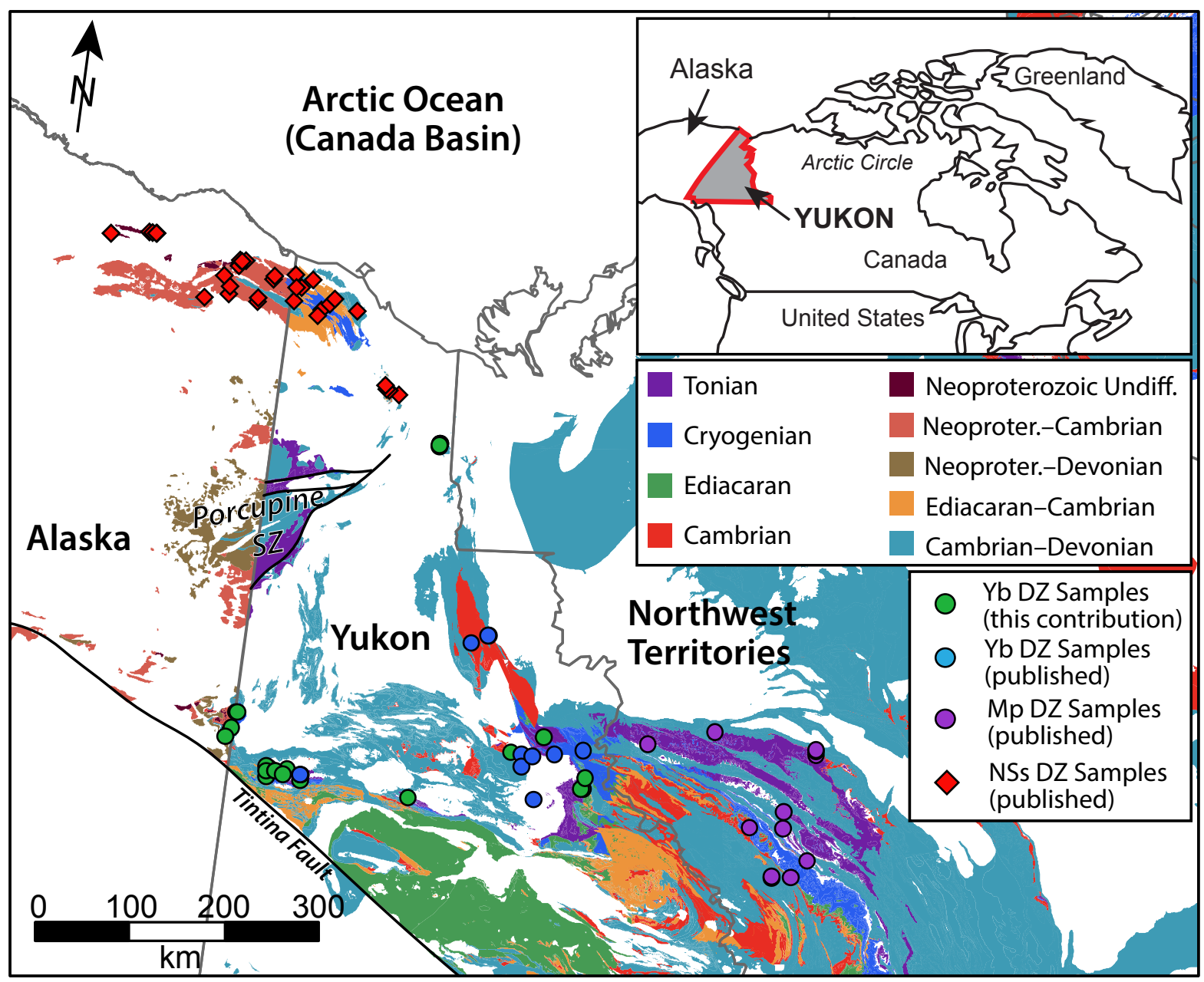


Figure S1. Simplified geological map of Neoproterozoic-Cambrian rocks in northeastern Alaska and northwestern Canada modified after Wilson et al. (2015) and Colpron et al. (2016) showing the locations of published and new samples reported herein (see Table S1). See Figure 1 from the main manuscript for the major terrane or paleogeographic element boundaries and note that only a small number of regionally significant faults are shown here. $\mathrm{Yb}$-Yukon block; MP—Mackenzie platform; NSs—North Slope subterrane; SZ-Shear Zone.

\section{Data Filtering}

All analyses in this compilation were filtered to exclude samples that do not overlap with concordia at the $2 \sigma$ level using error propagation. This was calculated starting from the equation for discordance:

$$
\operatorname{disc}=1-\left(\frac{t_{206 P b}}{\frac{238 U}{t_{207 P b}}}\right)=1-\frac{t_{68}}{t_{76}}=1-t_{68} t_{76}{ }^{-1}
$$

We incorporate the error propagation equation (assuming no covariance):

$$
\sigma_{x}^{2}=\sigma_{u}^{2}\left(\frac{\partial x}{\partial u}\right)^{2}+\sigma_{v}^{2}\left(\frac{\partial x}{\partial v}\right)^{2}+2 \sigma_{u v}^{2}\left(\frac{\partial x}{\partial u}\right)\left(\frac{\partial x}{\partial v}\right)
$$

Or:

$$
\sigma_{d i s c}^{2} \approx \sigma_{t 68}^{2}\left(\frac{\partial d i s c}{\partial t_{68}}\right)^{2}+\sigma_{t 76}^{2}\left(\frac{\partial d i s c}{\partial t_{76}}\right)^{2}
$$

We then compute the partial derivatives:

$$
\begin{gathered}
\left(\frac{\partial d i s c}{\partial t_{68}}\right)^{2}=\left(\frac{-1}{t_{76}}\right)^{2} \\
\left(\frac{\partial d i s c}{\partial t_{76}}\right)^{2}=\left(\frac{t_{68}}{\left(t_{76}\right)^{2}}\right)^{2}
\end{gathered}
$$

To produce the following error propagation equation:

$$
\sigma_{\text {disc }}^{2} \approx \sigma_{t 68}^{2}\left(\frac{-1}{t_{76}}\right)^{2}+\sigma_{t 76}^{2}\left(\frac{t_{68}}{\left(t_{76}\right)^{2}}\right)^{2}
$$


Analyses were then excluded where discordance was $>10 \%$ and/or reverse discordance was $>5 \%$ considering $2 \sigma$ uncertainty as follows:

$$
\begin{gathered}
\text { disc }-\sigma_{\text {disc }}^{2}>10 \% \\
\text { and } \\
d i s c+\sigma_{d i s c}^{2}<-5 \%
\end{gathered}
$$

Analyses were also excluded if the $2 \sigma$ uncertainty for either the ${ }^{206 *} \mathrm{~Pb} /{ }^{238} \mathrm{U}$ or ${ }^{207} \mathrm{~Pb} /{ }^{206} \mathrm{~Pb}$ date was $>10 \%$ of the isotopic date, regardless of which isotope system was employed for the "best age" selection (see details in Table S2 for new data presented herein).

After this filtering, only data from samples where $\mathrm{n} \geq 40$ were included in this compilation. All data that fit these criteria were then binned by stratigraphic age. The small sample size $(n=101)$ of the resulting Cryogenian age bin from the North Slope subterrane relative to all other age bins is ascribed to the paucity of Cryogenian strata preserved in Arctic Alaska. Therefore, in order to maintain statistically robust sample sizes, we combined the Cryogenian and Tonian age bins. All filtered data were placed into either a Tonian-Cryogenian, Ediacaran, or Cambrian time bin for statistical analysis using commonly applied non-parametric similarity-dissimilarity metrics (see below).

Individual sample data were sorted using cutoffs of 900,1200 , and $1500 \mathrm{Ma}$ for ${ }^{206 *} \mathrm{~Pb} /{ }^{238} \mathrm{U}$ versus ${ }^{207} \mathrm{~Pb} /{ }^{206} \mathrm{~Pb}$ dates. For grains with a ${ }^{206 *} \mathrm{~Pb} /{ }^{238} \mathrm{U}$ date younger than the cutoff, the ${ }^{206 *} \mathrm{~Pb} /{ }^{238} \mathrm{U}$ date was accepted as the "best age," and for grains older than the cutoff, the ${ }^{207} \mathrm{~Pb} /{ }^{206} \mathrm{~Pb}$ date was utilized. A 1500 Ma cutoff was applied for all the statistical analyses comparing age populations between the North Slope subterrane versus autochthonous northwestern Laurentia, as well as for the probability density plots (PDPs) and their qualitative descriptions presented below (Fig. S2). All three age cutoffs were also applied for self-comparison of the datasets to determine the effects on various statistical tests (see main text). 

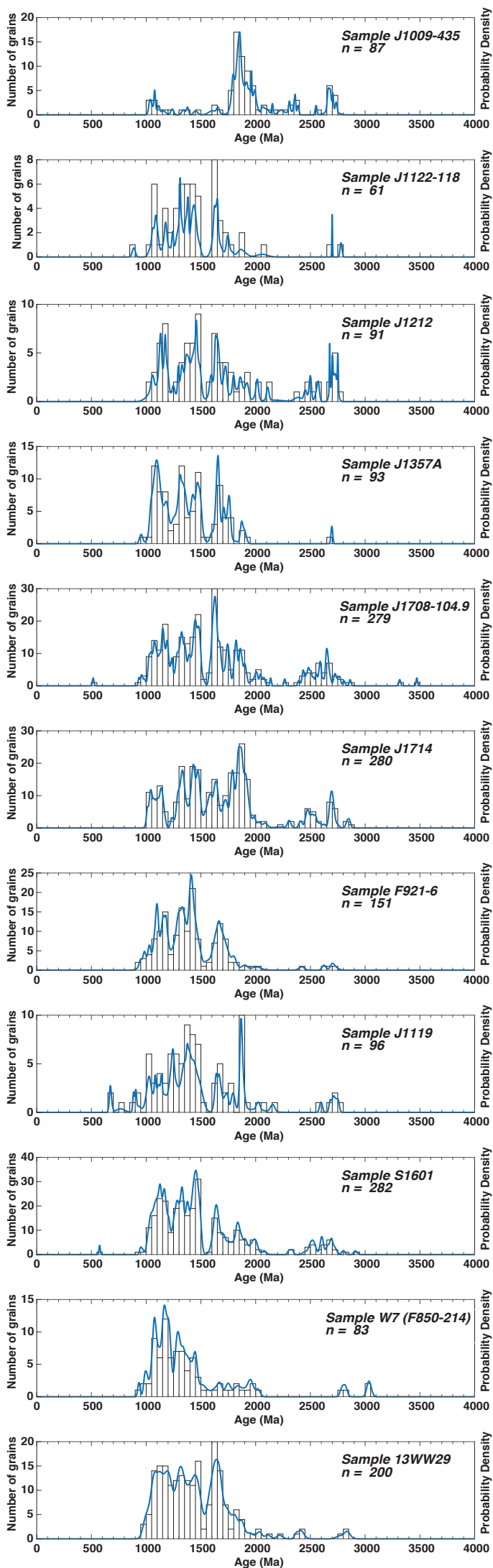
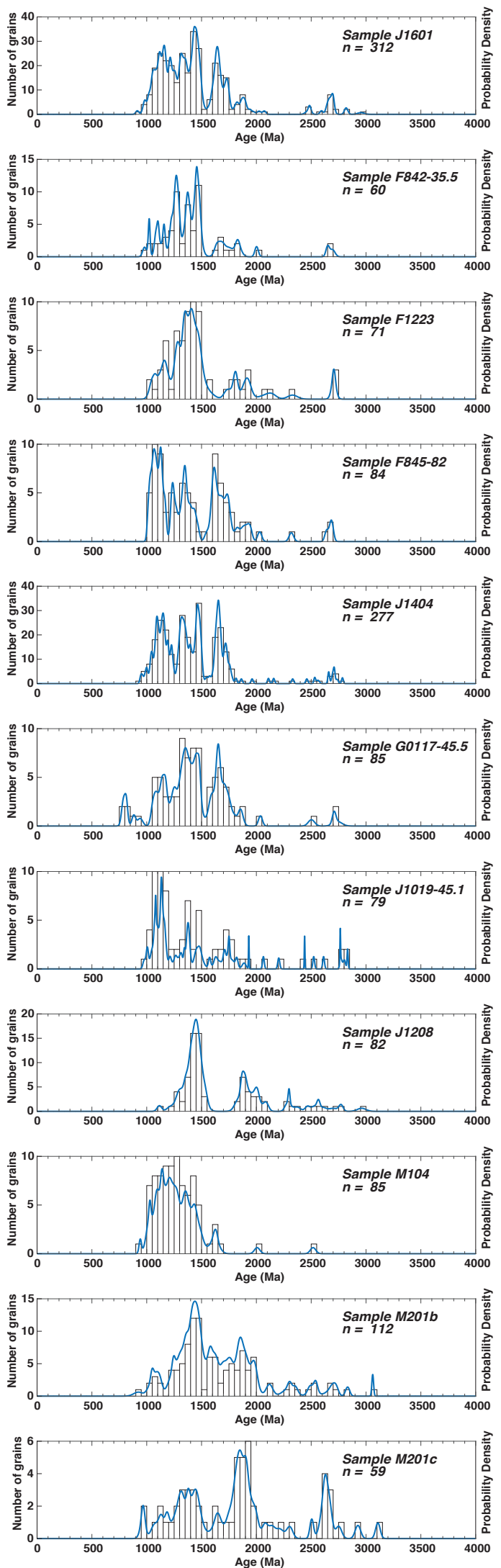

Figure S2. Histograms and probability density plots of individual new samples presented herein. 


\section{Statistical Analyses}

Detrital zircon geochronology U-Pb data from our compilation (Table S3) were analyzed using DZstats following methods outlined in Saylor and Sundell (2016) to test the null hypothesis that Neoproterozoic-Cambrian sandstone samples from the North Slope subterrane and northwestern Laurentian autochthon were derived from a common source region. Statistical values used to assess whether to accept or reject this null hypothesis (Table 1; Fig. 2) are approximated from Saylor and Sundell (2016). These values are not regarded as strict cutoffs, but rather rough guidelines for assessing the relative probability that two age populations of interest were drawn from the same parent population, assuming random sampling. We used five statistical metrics to evaluate the degree of similarity or dissimilarity between zircon age populations of interestCross-Correlation coefficient, Likeness coefficient, and Similarity coefficient were used to

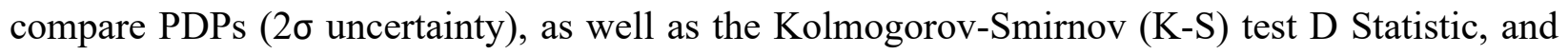
the Kuiper test V Statistic (see Figs. 2-3 in main text).

\section{Analytical Methods}

\section{Zircon Separation, Mounting, and Imaging}

Zircon was separated from sandstone samples for $\mathrm{U}-\mathrm{Pb}$ geochronology using standard mineral separation procedures (i.e., crushing, sieving, water density separation, magnetic separation, and heavy liquid density separation) at Dartmouth College, University of Iowa, and Boise State University. Separated zircon grains were mounted together with $\mathrm{U}-\mathrm{Pb}$ standards in a 1" epoxy ring, polished to expose their interiors, and then imaged using cathodoluminescence (CL) at the University of Iowa using a Gatan Chroma CL2 unit mounted on a Hitachi S3400 scanning electron microscope (SEM) or at Boise State University with a Gatan MiniCL unit mounted to a JEOL JSM-1300 SEM. Spot locations for laser ablation-inductively coupled plasma mass spectrometry (LA-ICPMS) were chosen from the CL images to avoid inherited cores, complex zonation, domain boundaries, and metamict zones.

\section{U-Pb LA-ICPMS Analyses}

Detrital zircon $\mathrm{U}-\mathrm{Pb}$ isotope ratios were analyzed by LA-ICPMS at the University of Arizona Laserchron Center (12 samples), Boise State University Isotope Geology Laboratory (8 samples), or the University of Adelaide (3 samples). These new data are reported in Table S2. 
University of Arizona Laserchron Center. Zircon grains from these twelve samples were ablated using a Photon Machines Analyte G2 Excimer laser with a HelEx ablation cell and analyzed using either a ThermoScientific Element2 single collector high resolution (HR)-ICPMS or $\mathrm{Nu}$ Instruments multicollector HR-ICPMS. Analytical procedures followed methods outlined in Gehrels et al. (2006, 2008) and Gehrels and Pecha (2014). For analyses using the Element2, which sequences rapidly through $\mathrm{U}, \mathrm{Th}$, and $\mathrm{Pb}$ isotopes, ion intensities were detected with a secondary electron multiplier (SEM). The SEM operates in pulse-counting mode for signals $<50 \mathrm{~K}$ cps, in both pulse-counting and analog mode for signals between $50 \mathrm{~K}$ and $4 \mathrm{M}$ cps, and in analog mode $>4 \mathrm{M}$ cps. Calibration between pulse-counting and analog signals was determined line-by-line for signals between $50 \mathrm{~K}$ and $4 \mathrm{M}$ cps and was applied to $4 \mathrm{M}$ cps signals. Four intensities were determined and averaged for each isotope, with dwell times of 0.0052 seconds for 202, 0.0075 seconds for 204, 0.0202 seconds for 206, 0.0284 seconds for 207, 0.0026 seconds for 208, 0.0026 seconds for 232, and 0.0104 seconds for 238. Zircons were ablated to a depth of $\sim 12 \mu \mathrm{m}$ using a spot diameter of $\sim 20 \mu \mathrm{m}$ at a rate of $\sim 0.8 \mu \mathrm{m} / \mathrm{s}$, using a laser energy density of $\sim 5 \mathrm{~J} / \mathrm{cm}^{2}$, a repetition rate of $8 \mathrm{~Hz}$, and an ablation time of 10 seconds. Sensitivity with these settings is $\sim 5,000 \mathrm{cps} / \mathrm{ppm}$. Each analysis consists of 5 seconds counting on peaks with the laser off for backgrounds and 10 seconds with the laser firing for peak intensities. This is followed by a 20 second delay to purge the previous sample and save files.

Analyses conducted with the $\mathrm{Nu}$ Instruments HR-ICPMS were made in static mode using Faraday collectors with $3 \times 10^{11} \mathrm{ohm}$ resistors for measuring ${ }^{238} \mathrm{U},{ }^{232} \mathrm{Th},{ }^{208} \mathrm{~Pb}-{ }^{206} \mathrm{~Pb}$, and ion counters for ${ }^{204} \mathrm{~Pb}$ and ${ }^{202} \mathrm{Hg}$. Zircons were ablated to a depth of $\sim 12 \mu \mathrm{m}$ at a rate of $\sim 0.8 \mu \mathrm{m} / \mathrm{s}$, using a spot diameter of $\sim 30 \mu \mathrm{m}$, and ablated material was carried in Helium gas to the plasma source. Ion yields are $\sim 0.8 \mathrm{mv}$ per ppm, and each analysis consisted of a single 15 second integration on peaks with the laser off for backgrounds, then 15 one-second integrations with the laser firing, and a 30 second delay to completely purge the previous sample prior to the next analysis.

All sample analyses were bracketed with the Sri Lanka $\left({ }^{206} \mathrm{~Pb} /{ }^{238} \mathrm{U}\right.$ age of $563.2 \pm 4.8 \mathrm{Ma}$, $2 \sigma$; Gehrels et al., 2008), R33 ( ${ }^{206} \mathrm{~Pb} /{ }^{238} \mathrm{U}$ age of $420.53 \pm 0.16 \mathrm{Ma}, 2 \sigma$; Mattinson, 2010), and FC1 $\left({ }^{207} \mathrm{~Pb} /{ }^{206} \mathrm{~Pb}\right.$ age of $1099.0 \pm 0.6 \mathrm{Ma}, 2 \sigma$; Paces and Miller, 1993) reference zircons to assess reproducibility. ${ }^{204} \mathrm{Hg}$ interference with ${ }^{204} \mathrm{~Pb}$ was taken into account for ${ }^{202} \mathrm{Hg}$ measurement during 
laser ablation and ${ }^{204} \mathrm{Hg}$ was subtracted according to the natural ${ }^{202} \mathrm{Hg} /{ }^{204} \mathrm{Hg}$ ratio of 4.35. This $\mathrm{Hg}$ correction is not significant for most analyses because $\mathrm{Hg}$ backgrounds are low at the Laserchron facility (generally $\sim 150 \mathrm{cps}$ at mass 204 ). Common $\mathrm{Pb}$ corrections are calculated using the $\mathrm{Hg}$-corrected ${ }^{204} \mathrm{~Pb}$ values and assuming an initial $\mathrm{Pb}$ composition (Stacey and Kramers, 1975). Uncertainties for ${ }^{206} \mathrm{~Pb} /{ }^{204} \mathrm{~Pb}(1.5 \%)$ and ${ }^{207} \mathrm{~Pb} /{ }^{204} \mathrm{~Pb}(0.3 \%)$ were applied to these compositional values based on variation in the $\mathrm{Pb}$ isotopic composition of crystalline rocks. For each analysis, the errors in determining ${ }^{206} \mathrm{~Pb} /{ }^{238} \mathrm{U}$ and ${ }^{206} \mathrm{~Pb} /{ }^{204} \mathrm{~Pb}$ resulted in a measurement error of $\sim 1-2 \%$ (at $2 \sigma$ level) in the ${ }^{206} \mathrm{~Pb} /{ }^{238} \mathrm{U}$ age. Errors in ${ }^{207} \mathrm{~Pb} /{ }^{206} \mathrm{~Pb}$ and ${ }^{206} \mathrm{~Pb} /{ }^{204} \mathrm{~Pb}$ measurements also result in $\sim 1-2 \%$ (at $2 \sigma$ level) uncertainty in age for grains that are $>1000$ Ma but are substantially larger for younger grains due to the low intensity of the ${ }^{207} \mathrm{~Pb}$ signal. Uncertainties on the U-Pb isotopic data include only measurement errors. These background-corrected analytical data were reduced from raw ratios to ${ }^{206} \mathrm{~Pb} /{ }^{238} \mathrm{U},{ }^{207} \mathrm{~Pb} /{ }^{235} \mathrm{U}$, and ${ }^{207} \mathrm{~Pb} /{ }^{206} \mathrm{~Pb}$ ratios, which were used to calculate apparent ages using the AgeCalc macro. Raw data and calculated "best ages" using 900, 1200, and 1500 Ma cutoffs are presented in Table S2.

Boise State University Isotope Geology Laboratory. Zircons were analyzed using a ThermoElectron X-Series II quadrupole ICPMS and New Wave Research UP-213 Nd:YAG UV $(213 \mathrm{~nm})$ laser ablation system. In-house analytical protocols, standard materials, and data reduction software were used to acquire and calibrate $\mathrm{U}-\mathrm{Pb}$ dates, a suite of high field strength elements (HFSEs), and rare earth elements (REEs).

During analyses, zircon grains were ablated with a $25 \mu \mathrm{m}$ diameter laser spot, using fluence and pulse rates of $5 \mathrm{~J} / \mathrm{cm}^{2}$ and $10 \mathrm{~Hz}$, respectively, for 45 seconds (15 second gas blank, 30 second ablation) that excavated a $\sim 25 \mu \mathrm{m}$ deep pit. Ablated material was carried via He gas stream at a rate of $1.2 \mathrm{~L} /$ minute to the plasma. Dwell times were $5 \mathrm{~ms}$ for $\mathrm{Si}$ and $\mathrm{Zr}, 200 \mathrm{~ms}$ for ${ }^{49} \mathrm{Ti}$, then subtracted from the raw count rate for each analyte. Ablation pits that seem to have intersected glass or mineral inclusions were identified based on $\mathrm{Ti}$ and $\mathrm{P}$ anomalies. U-Pb dates calculated from these analyses are considered valid if the $\mathrm{U}-\mathrm{Pb}$ ratios do not appear to have been affected by the inclusions. Analyses with mass 204 values above baseline are interpreted to reflect common $\mathrm{Pb}$ contamination were rejected. Background-subtracted count rates for elemental concentrations were each normalized to ${ }^{29} \mathrm{Si}$ and calibrated to NIST SRM-610 and NIST SRM--612 standards. Crystallization temperature was calculated from the Ti-in-zircon thermometer (Watson et al., 
2006). Because there are no constraints on the activity of $\mathrm{TiO}_{2}$, an average value in crustal rocks of 0.8 was used.

Instrumental fractionation from background-subtracted ratios was corrected when calculating $\mathrm{U}-\mathrm{Pb}$ and ${ }^{207} \mathrm{~Pb} /{ }^{206} \mathrm{~Pb}$ dates. These dates were also calibrated with interspersed zircon standards and reference materials analyses. Two analyses of the primary Plešovice zircon standard (Sláma et al., 2008) for every 10 unknown analyses were used to monitor time-dependent instrumental fractionation. Then, a secondary correction to ${ }^{206} \mathrm{~Pb} /{ }^{238} \mathrm{U}$ dates was made from analyses of the Seiland (530 Ma, unpublished data, Boise State University Isotope Geology Laboratory) and 15PS123 standards (173 Ma, unpublished data, Boise State University Isotope Geology Laboratory). These zircon standards were measured once per 10 unknown analyses. Results from standard analyses exhibit a linear age bias of several percent, which is related to the ${ }^{206} \mathrm{~Pb}$ count rate, and so the secondary correction helps to mitigate matrix-dependent variations due to contrasting compositions and ablation characteristics between the Plešovice zircon standard and other standards and unknowns.

Radiogenic isotope ratio and date uncertainty propagation for all analyses includes uncertainty contributions from counting statistics and background subtraction. A standard calibration uncertainty is propagated into uncertainties. This standard calibration uncertainty is the local standard deviation of the polynomial fit to the interspersed primary standard measurements versus time for the $\mathrm{U} / \mathrm{Pb}$ fractionation factor; these uncertainties range from 1.06 to $1.33 \%(2 \sigma)$ for ${ }^{206} \mathrm{~Pb} /{ }^{238} \mathrm{U}$ dates. Raw data and calculated "best ages" using 900, 1200, and 1500 Ma cutoffs are presented in Table S2.

University of Adelaide. Zircon grains were analyzed at the University of Adelaide using an Agilent 7500 cs ICPMS coupled with a New Wave New Wave $(213 \mathrm{~nm})$ Nd-YAG laser with a spot size of $30 \mu \mathrm{m}$, frequency of $5 \mathrm{~Hz}$, and a laser intensity of $75 \%$. Data acquisition involved 40 seconds background measurement, 10 seconds of beam stabilization, and 30 seconds sample ablation. Isobaric interference of ${ }^{204} \mathrm{Hg}$ means corrections for common $\mathrm{Pb}$ where not made; however, mass 204 was monitored and analyses showing above background counts of mass 204 were discarded. Other operating conditions and equipment utilized are outlined by Payne et al. (2006). Zircon standard GJ-1 $\left({ }^{206} \mathrm{~Pb} /{ }^{238} \mathrm{U}\right.$ age $=600.7 \pm 1.1 \mathrm{Ma}$ and ${ }^{207} \mathrm{~Pb} /{ }^{235} \mathrm{U}$ age $=602.2 \pm 1.0 \mathrm{Ma}($ Jackson et al., 2004)) was used as a primary standard and Plešovice $\left({ }^{206} \mathrm{~Pb} /{ }^{238} \mathrm{U}\right.$ age $=337.13 \pm 0.37 \mathrm{Ma}$, 
(Sláma et al., 2008)) was used as a secondary standard. U-Pb fractionation was corrected using the GEMOC GJ-1 zircon standard (TIMS normalization data ${ }^{207} \mathrm{~Pb} /{ }^{206} \mathrm{~Pb}=608.3 \mathrm{Ma},{ }^{206} \mathrm{~Pb} /{ }^{238} \mathrm{U}=$ $600.7 \mathrm{Ma}$ and ${ }^{207} \mathrm{~Pb} /{ }^{235} \mathrm{U}=602.2 \mathrm{Ma}$, Jackson et al., 2004) and accuracy was checked using an inhouse Sri Lankan zircon standard (BJWP-1, ca. $727 \mathrm{Ma}$ ). Data were then processed using Iolite (Hellstrom et al., 2008) for isotopic ages and $\mathrm{U}$ and Th counts.

\section{SUPPLEMENTAL RESULTS}

\section{Sample Descriptions}

\section{Cambrian}

J1009-435. Sample J1009-435 is from the upper Cambrian-Middle Ordovician Jones Ridge Formation of the Tadonduk inlier along the Yukon-Alaska border (Fig. S1; Tables S1, S2; Young, 1982; Taylor et al., 2015). This sample was collected from an $\sim 30 \mathrm{~cm}$ thick quartz arenite bed directly above a prominent $\sim 5 \mathrm{~m}$ thick paleokarst horizon, which marks the contact between the lower Cambrian Funnel Creek and upper Cambrian Jones Ridge formations (Taylor et al., 2015). This sample has a prominent 1700-2000 Ma age population with an 1850 Ma peak, a secondary 2650-2750 Ma population, and subordinate 1000-1100 and 2300-2400 Ma age peaks (Fig. S2). It also contains minor abundances of 1100-1700, 2000-2300, and 2400-2700 Ma grains. The youngest concordant zircons that pass our filters are $1032 \pm 19,1044 \pm 28$, and $1047 \pm 36 \mathrm{Ma}(2 \sigma)$.

J1122-118. Sample J1122-118 is from the middle-upper Cambrian Slats Creek Formation or informal map unit Csc in the Hart River inlier of north-central Yukon (Fig. S1; Tables S1, S2; Abbott, 1997). This sample of coarse-grained quartz wacke was collected from an irregular $\sim 2-\mathrm{m}-$ deep quartz-sand filled paleokarst horizon developed on the underlying Tonian Callison Lake Formation (Strauss et al., 2015). Prominent U-Pb age populations from this sample range from 1050-1500 and 1600-1900 Ma, with discrete peaks at 1300, 1375, 1450, and $1650 \mathrm{Ma}$ (Fig. S2). Additionally, there are single grains at ca. 2060, 2700, and $2780 \mathrm{Ma}$. The youngest concordant zircons that pass our filters are $887 \pm 27,1041 \pm 46$, and $1060 \pm 18 \mathrm{Ma}(2 \sigma)$.

J1212. Sample J1212 is from the lower Cambrian Illtyd Formation in the Illtyd Range of northeastern Yukon (Fig. S1; Tables S1, S2; Fritz, 1991). This sample of medium-grained hematite-cemented quartz wacke was collected $\sim 76 \mathrm{~m}$ above the basal contact with the 
Paleoproterozoic Quartet Group in the type section of the Illtyd Formation (Fritz, 1991, 1997). Prominent $\mathrm{U}-\mathrm{Pb}$ age populations from this sample range from 1000-1200, 1300-1500, 16001700 , and 2650-2750 Ma, with scattered populations of 1700-2100 and 2500-2600 Ma grains (Fig. S2). The youngest concordant zircons that pass our filters are $1014 \pm 68,1046 \pm 43$, and 1061 $\pm 27 \mathrm{Ma}(2 \sigma)$.

J1357A. Sample J1357A is from the lower Cambrian Illtyd(?) Formation or informal map unit C1 in the White Uplift of northern Yukon (Fig. S1; Tables S1, S2; Norris, 1981, 1997; Morrow, 1989; Dyke, 1997; Fritz, 1997). This sample was collected from medium-grained quartz arenite with abundant Skolithos burrows, $\sim 0.5 \mathrm{~m}$ above an angular unconformity with unnamed Ediacaran siliciclastic rocks of informal map unit Pu (Dyke, 1997; Strauss, unpublished data). Prominent U$\mathrm{Pb}$ age populations from this sample range from 1050-1200, 1250-1400, 1450-1500, and 1600$1700 \mathrm{Ma}$, with a subordinate 1750-1800 Ma peak and small 1900-2000 Ma peak (Fig. S2). The youngest concordant zircons that pass our filters are $954 \pm 29,1041 \pm 22$, and $1050 \pm 53 \mathrm{Ma}(2 \sigma)$.

J1708-104.9. Sample J1708-104.9 is from the lower-middle Cambrian Shell Creek Formation (previously map unit PH5, Mustard and Roots, 1997) in the Coal Creek inlier of west-central Yukon (Fig. S1; Tables S1, S2; Busch et al., accepted). This sample was collected from a $<30 \mathrm{~cm}$ thick trough cross-bedded medium- to coarse-grained sublitharenite horizon interbedded with polymict cobble conglomerate just above the sub-Shell Creek unconformity (Busch et al., accepted). The most prominent $\mathrm{U}-\mathrm{Pb}$ age peak in this sample is between 1550 and $1700 \mathrm{Ma}$, and other major age populations include 1000-1200, 1250-1350, 1400-1500, 1700-1750, and 1800$1950 \mathrm{Ma}$ (Fig. S2). There are also smaller 1950-2150 and 2350-2900 Ma age populations and individual ca. 3300 and 3470 Ma grains. The youngest concordant zircons that pass our filters are $516 \pm 13,934 \pm 14$, and $957 \pm 18 \mathrm{Ma}(2 \sigma)$.

J1714. Sample J1714 is from the lower-middle Cambrian Shell Creek Formation (previously map unit PH5, Mustard et al., 1988) in the Coal Creek inlier of west-central Yukon (Fig. S1; Tables S1, S2; Busch et al., accepted). This sample was collected $\sim 7 \mathrm{~m}$ above an erosional contact with the early Ediacaran Mount Ina Formation and consists of amalgamated fine-grained lithic arenite to sublitharenite with planar lamination. This sample contains prominent $\mathrm{U}-\mathrm{Pb}$ age populations that 
range from 1000-1200, 1250-1350, 1400-1500, 1550-1650, 1700-1950, and 2650-2750 Ma (Fig. S2). There are additional smaller populations between 1950 and $2900 \mathrm{Ma}$, and the youngest concordant zircons that pass our filters are $1009 \pm 27,1011 \pm 14$, and $1013 \pm 23 \mathrm{Ma}(2 \sigma)$.

\section{Ediacaran}

F921-6. Sample F921-6 is from the Ediacaran Last Chance Formation (previously map unit PH4, Mustard and Roots, 1997) in the Coal Creek inlier of west-central Yukon (Fig. S1; Tables S1, S2; Busch et al., accepted). This sample was collected from amalgamated, hummocky cross-stratified very fine-grained calcareous quartz arenite approximately $6 \mathrm{~m}$ above the top of the informal Gladman member (Busch et al., accepted). Prominent $\mathrm{U}-\mathrm{Pb}$ age populations from this sample range from 1020-1100, 1150-1200, 1250-1350, 1350-1500, and 1600-1850 Ma (Fig. S2). There are also individual zircon grains scattered between 1900 and $2725 \mathrm{Ma}$, and the youngest concordant zircons that pass our filters are $948 \pm 24,949 \pm 61$, and $979 \pm 29 \mathrm{Ma}(2 \sigma)$.

J1119. Sample J1119 is from the Ediacaran upper Tindir Group in the Tatonduk inlier of the Yukon-Alaska border region (Fig. S1; Tables S1, S2; Young, 1982; Macdonald et al., 2018). This sample was collected along the Tatonduk River from a very coarse-grained and normal graded sublitharenite horizon interbedded with grey-black shale. This sample contains a broad U-Pb age population from 1000-1550 Ma with peaks at ca. 1250, 1350-1400, and 1850-1950 Ma (Fig. S2). There are additional small zircon populations between 670-930 and 2000-2750 Ma, and the youngest concordant zircons that pass our filters are $672 \pm 15,677 \pm 26$, and $766 \pm 74 \mathrm{Ma}(2 \sigma)$.

S1601. Sample S1601 is from an Ediacaran portion of undifferentiated map unit $\mathrm{Pu}$ in the White Uplift of northern Yukon (Fig. S1; Tables S1, S2; Norris, 1981, 1997; Morrow, 1989; Dyke, 1997; Strauss, unpublished data). This sample was collected from a $>4 \mathrm{~m}$ thick horizon of trough crossstratified and silica-cemented quartz arenite directly beneath the lower Cambrian Illtyd(?) Formation (Fritz, 1997) or informal map unit C1 (Morrow, 1989). Prominent U-Pb age populations occur between 1000-1200 and 1250-1500 Ma with smaller age peaks between 1600-1750 and 1800-2000 Ma (Fig. S2). There is also a moderately small U-Pb age population between 2450 and $2900 \mathrm{Ma}$. The youngest concordant zircons that pass our filters are $575 \pm 12,948 \pm 18$, and $967 \pm$ $22 \mathrm{Ma}(2 \sigma)$. 
W7 (F850-214). Sample W7 is from the Ediacaran Gametrail Formation in the Wernecke inlier of eastern Yukon (Fig. S1; Tables S1, S2; Macdonald et al., 2018). The sample was collected from the base of a well-sorted, medium-grained quartz arenite horizon with minor, shard-like lithic fragments. Prominent U-Pb age populations from this sample range from 1050-1300 and 1300$1500 \mathrm{Ma}$, with scattered 930-1050 and 1500-2020 Ma populations and a small proportion of grains between 2790 and $3045 \mathrm{Ma}$ (Fig. S2). The youngest concordant zircons that pass our filters are $934 \pm 22,988 \pm 28$, and $993 \pm 25 \mathrm{Ma}(2 \sigma)$.

\section{Cryogenian}

13WW29. Sample $13 \mathrm{WW} 29$ is from a Cryogenian portion of undifferentiated map unit $\mathrm{Pu}$ in the White Uplift of northern Yukon (Fig. S1; Tables S1, S2; Norris, 1981, 1997; Morrow, 1989; Dyke, 1997; Strauss, unpublished data). This sample was collected from an $\sim 6 \mathrm{~m}$ thick outcrop of poorly exposed hematite-cemented quartz wacke that sits $\sim 3 \mathrm{~m}$ above mafic volcanic and volcaniclastic rocks of an unnamed volcanic unit. This sample has a broad $\mathrm{U}-\mathrm{Pb}$ age population between 1000 and $1500 \mathrm{Ma}$, a prominent 1550-1750 Ma population, and a minor 1800-1900 Ma population (Fig. S2). Additionally, there are scattered ca. 1950-2850 Ma grains. The youngest concordant zircons that pass our filters are $988 \pm 49,990 \pm 42$, and $991 \pm 49 \mathrm{Ma}(2 \sigma)$.

J1601. Sample J1601 is from a Cryogenian portion of undifferentiated map unit $\mathrm{Pu}$ in the White Uplift of northern Yukon (Fig. S1; Tables S1, S2; Norris, 1981, 1997; Morrow, 1989; Dyke, 1997; Strauss, unpublished data). This sample was collected from the same $\sim 6 \mathrm{~m}$ thick outcrop of poorly exposed hematite-cemented quartz wacke that was sampled in 13WW29 above. This sample has prominent $\mathrm{U}-\mathrm{Pb}$ age populations that range from 1000-1250, 1250-1500, and 1550-1750 Ma, and subordinate populations from 1800-2070 and 2450-2950 Ma (Fig. S2). The youngest concordant zircons that pass our filters are $914 \pm 28,972 \pm 30$, and $978 \pm 32 \mathrm{Ma}(2 \sigma)$.

F842-35.5. Sample F842-35.5 is from the Cryogenian Eagle Creek Formation of the Coal Creek inlier in west-central Yukon (Fig. S1; Tables S1, S2; Macdonald et al., 2018). This sample was collected from fine- to medium-grained silty quartz wacke with rare cobble-sized clasts of dolostone, quartzite, and mafic volcanic rocks. Prominent U-Pb age populations in this sample 
range from 1200-1300 and 1350-1500 Ma (Fig. S2); smaller ca. 980-1160 and 1600-1850 Ma populations also exist. There is a single ca. 2000 Ma grain and two grains between 2650-2700 Ma. The youngest concordant zircons that pass our filters are $980 \pm 34,1021 \pm 22$, and $1023 \pm 13 \mathrm{Ma}$ $(2 \sigma)$.

F1223. Sample F1223 is from the Cryogenian Twitya Formation in the Wernecke inlier of eastern Yukon (Fig. S1; Tables S1, S2; Macdonald et al., 2018). This sample was collected from a thinbedded sandy green siltstone horizon within thick-bedded polymict conglomerate of the basal Twitya Formation that rests disconformably on the Tonian Hematite Creek Group (Eisbacher, 1981; Macdonald et al., 2018). Prominent U-Pb age populations from this sample range from 1000-1200 and 1250-1500 Ma, and smaller populations occur between 1700-1950 Ma and ca. $2700 \mathrm{Ma}$ (Fig. S2). There are also scattered populations of ca. 1550 and 2050-2150 Ma grains. The youngest concordant zircons that pass our filters are $1034 \pm 49,1049 \pm 35$, and $1076 \pm 30 \mathrm{Ma}$ $(2 \sigma)$.

\section{Tonian}

F845-82. Sample F845-82 is from the informal "upper shale" unit of the upper Fifteenmile Group in the Tatonduk inlier along the Alaska-Yukon border (Fig. S1; Tables S1, S2; Macdonald et al., 2011; Macdonald and Cohen, 2011). This sample consists of coarse-grained quartz arenite collected from a m-scale channel within black and gray shale that is interbedded with lime mudstone and calcisiltite from just northwest of Mount Slipper. This sample contains prominent $\mathrm{U}-\mathrm{Pb}$ age populations that range from 1000-1170, 1230-1450, and 1600-1800 Ma, with scattered populations between 1800-2030 and 2640-2690 Ma (Fig. S2). The youngest concordant zircons that pass our filters are $1016 \pm 24,1018 \pm 25$, and $1032 \pm 23 \mathrm{Ma}(2 \sigma)$.

J1404. Sample J1404 is from the Tonian upper Fifteenmile Group of the Tatonduk inlier along the Alaska-Yukon border region (Fig. S1; Tables S1, S2; Macdonald et al., 2011; Macdonald and Cohen, 2011). This sample was collected from the same horizon as F845-82. Prominent U-Pb age populations from this sample range from 1000-1250, 1300-1500, and 1600-1800 Ma, with scattered populations between 2000 and $2785 \mathrm{Ma}$ (Fig. S2). The youngest concordant zircons that pass our filters are $945 \pm 18,957 \pm 24$, and $964 \pm 22 \mathrm{Ma}(2 \sigma)$. 
G0117-45.5. Sample G0117-45.5 is from the upper Fifteenmile Group of the Tatonduk inlier along the Alaska-Yukon border (Fig. S1; Tables S1, S2; Macdonald et al., 2011; Macdonald and Cohen, 2011). The sample was collected from a light green tuffaceous lithic wacke within the "upper carbonate" unit on the west side of Mount Slipper, approximately $15 \mathrm{~m}$ above a black shale horizon that is dated to $810.7 \pm 6.3 \mathrm{Ma}$ (Cohen et al., 2017). This horizon is approximately correlative with the $811.51 \pm 0.25 \mathrm{Ma}$ tuff interbedded within Reefal assemblage carbonates in the upper Fifteenmile Group from the Coal Creek inlier (Macdonald et al., 2010). There are prominent U-Pb peaks in this sample that span 1050-1200, 1250-1500, and 1580-1860 Ma (Fig. S2). Additionally, there are subordinate peaks at 785 and $940 \mathrm{Ma}$ and scattered populations between 2000 and 2750 Ma. The youngest concordant zircons that pass our filters are $785 \pm 35,793 \pm 38$, and $802 \pm 42$ Ma $(2 \sigma)$, which are all within uncertainty of previous geochronological data for this unit (Macdonald et al., 2010; Cohen et al., 2017). This sample was originally processed as a tuff, and faceted zircon grains were preferentially picked for analysis. As a result, the ca. $800 \mathrm{Ma}$ peak $(\mathrm{n}=4)$ is disproportionately large and does not represent the true distribution of this age population in the sample. However, these four grains do not affect our statistical results.

J1019-45.1. Sample J1019-45.1 is from the Tonian Callison Lake Formation in the Coal Creek inlier of Yukon (Fig. S1; Tables S1, S2; Strauss et al., 2015). This sample was collected from a poorly sorted quartz wacke horizon that rests disconformably on the underlying Craggy Dolostone of the Fifteenmile Group (Strauss et al., 2015). This sample contains a prominent 1000-1200 Ma $\mathrm{U}-\mathrm{Pb}$ age population, and subordinate peaks that range from 1300-1400 and 1700-1800 Ma (Fig. S2). There are also smaller populations between 1200-1300, 1400-1700, and 1800-2930 Ma. The youngest concordant zircons that pass our filters are $977 \pm 24,1003 \pm 22$, and $1007 \pm 18 \mathrm{Ma}(2 \sigma)$.

J1208. Sample J1208 is from the Tonian Chandindu Formation (Fifteenmile Group) of the Coal Creek inlier of Yukon (Fig. S1; Tables S1, S2; Macdonald et al., 2012; Kunzmann et al., 2014). This sample consists of fine- to medium-grained lithic arenite and comes from just below the first major patch reef of the Reefal assemblage. This sample is dominated by a prominent 1200-1550 $\mathrm{U}-\mathrm{Pb}$ age population and subordinate 1800-2100 Ma population (Fig. S2). There are small 
populations spread evenly between $2270-2960$ Ma. The youngest concordant zircons that pass our filters are $1116 \pm 42,1212 \pm 57$, and $1275 \pm 67 \mathrm{Ma}(2 \sigma)$.

M104. Sample M104 is from the Tonian Tarn Lake Formation, just west of Mount Profeit in the Wernecke inlier of Yukon (Fig. S1; Tables S1, S2; Turner et al., 2011). This sample was collected from an outcrop of fine-grained gray-green quartz arenite. The sample is characterized by a single, broad U-Pb age population between 1000 and $1500 \mathrm{Ma}$, as well as a minor 1590-1650 Ma zircons (Fig. S2). There are also individual ca. 940, 2000, and 2500 Ma grains. The youngest concordant zircons that pass our filters are $941 \pm 22,1012 \pm 39$, and $1014 \pm 48 \mathrm{Ma}(2 \sigma)$.

M201b. Sample M201b is from the Tonian Reefal assemblage (upper Fifteenmile Group) in the Coal Creek inlier of Yukon (Fig. S1; Tables S1, S2; Macdonald et al., 2012). This sample was collected from an outcrop of finely laminated sandy mudstone interbedded with silicified stromatolitic dolostone. There are is a broad $\mathrm{U}-\mathrm{Pb}$ age population in this sample that ranges from 1000-2000 Ma, with prominent peaks between 1400-1500 and 1800-1900 Ma and a smaller peak at ca. $1050 \mathrm{Ma}$ (Fig. S2). There are also scattered U-Pb age populations between 2100 and 3060 Ma. The youngest concordant zircons that pass our filters are $924 \pm 84,1024 \pm 50$, and $1049 \pm 27$ $\operatorname{Ma}(2 \sigma)$.

M201c. Sample M201c is from the Tonian Reefal assemblage (upper Fifteenmile Group) in the Coal Creek inlier of Yukon (Fig. S1; Tables S1, S2; Macdonald et al., 2012). This sample was collected 1 meter above sample M201b and consists of finely laminated brown sandy siltstone interbedded with silicified stromatolitic dolostone. Prominent $\mathrm{U}-\mathrm{Pb}$ age populations from this sample range from 1050-1520, 1660-2300, and 2600-2700 Ma, with a smaller population of 950$1000 \mathrm{Ma}$ and scattered 2750-3100 Ma grains (Fig. S2). The youngest concordant zircons that pass our filters are $963 \pm 50,968 \pm 32$, and $1068 \pm 61 \mathrm{Ma}(2 \sigma)$. 


\section{REFERENCES CITED}

Abbott, J.G. 1997. Geology of the upper Hart River area, eastern Ogilvie Mountains, Yukon Territory (116A/10, 116A/11). Indian and Northern Affairs Canada, Exploration and Geological Services Division, Yukon Region, v. 9, 92 p.

Busch, J.F., Rooney, A.D., Meyer, E.E., Town, C., Moynihan, D., and Strauss, J.V., accepted, Late Neoproterozoic-early Paleozoic basin evolution in the Coal Creek inlier of Yukon, Canada: Implications for the tectonic evolution of northwestern Laurentia: Canadian Journal of Earth Sciences, v. xx, p. xxx.

Cohen, P.A., Strauss, J.V., Rooney, A.D., Sharma, M. and Tosca, N., 2017. Controlled hydroxyapatite biomineralization in an $\sim 810$ million-year-old unicellular eukaryote: Science Advances, v. 3, no. 6, p.e1700095.

Colpron, M., Israel, S., Murphy, D., Pigage, L., and Moynihan, D., 2016, Yukon bedrock geology map: Yukon Geological Survey, Open File report, v. 1.

Colpron, M., McClelland, W. C., and Strauss, J. V., 2019, Detrital zircon U-Pb geochronological and Hf isotopic constraints on the geological evolution of North Yukon, in Piepjohn, K., Strauss, J.V., Reinhardt, L., and McClelland, W.C., eds., Circum-Arctic Structural Events: Tectonic Evolution of the Arctic Margins and Trans-Arctic Links with Adjacent Orogens: Geological Society of America Special Paper 541, p. 497-437.

Dyke, L.D., 1997, White, Barn and Campbell uplifts, in Norris, D.K. 1997. The Geology, mineral and hydrocarbon potential of northern Yukon Territory and northwestern District of Mackenzie: Geological Survey of Canada Bulletin, v. 422, p. 21-64.

Eisbacher, G.H., 1981. Sedimentary tectonics and glacial record in the Windermere Supergroup, Mackenzie Mountains, northwestern Canada: Geological Survey Paper 80-27.

Fritz, W.H., 1991. Lower Cambrian trilobites from the Illtyd Formation, Wernecke Mountains, Yukon Territory, Geological Survey of Canada Bulletin, v. 409, 77 p.

Fritz, W.H. 1997. Cambrian, in Norris, D.K., Geology and Mineral and Hydrocarbon Potential of Northern Yukon Territory and Northwestern District of Mackenzie: Geological Survey of Canada Bulletin, v. 422, p. 85-117.

Gehrels, G.E., and Pecha, M., 2014, Detrital zircon U-Pb geochronology and Hf isotope geochemistry of Paleozoic and Triassic passive margin strata of western North America: Geosphere, v. 10, no. 1, p. 49-65.

Gehrels, G. E., Valencia, V., and Ruiz, J., 2008, Enhanced precision, accuracy, efficiency, and spatial resolution of $\mathrm{U}-\mathrm{Pb}$ ages by laser ablation-multicollector-inductively coupled plasma-mass spectrometry: Geochemistry, Geophysics, Geosystems: v. 9, Q03017.

Gehrels, G. E., Valencia, V., and Pullen, A., 2006, Detrital zircon geochronology by LaserAblation Multicollector ICPMS at the Arizona LaserChron Center, in Loszewski, T., and Huff, W., eds., Geochronology: Emerging Opportunities, Paleontology Society Short Course: Paleontology Society Papers, v. 11, 10 p. Stacey, J. S., and Kramers, J. D., 1975, Approximation of terrestrial lead isotope evolution by a two- stage model: Earth and Planetary Science Letters, v. 26, p. 207-221.

Hadlari, T., Davis, W.J., Dewing, K., Heaman, L.M., Lemieux, Y., Ootes, L., Pratt, B.R. and Pyle, L.J., 2012, Two detrital zircon signatures for the Cambrian passive margin of northern Laurentia highlighted by new U-Pb results from northern Canada: Geological Society of America Bulletin, v. 124, no. 7-8, p. 1155-1168. 
Hellstrom, J., Paton, C., Woodhead, J., Hergt, J., 2008, Iolite: software for spatially resolved LA(quad and MC) ICPMS analysis. Mineralogical Association of Canada short course series 40, p. 343-348.

Jackson, S.E., Pearson, N.J., Griffin, W.L., Belousova, E.A., 2004, The application of laser ablation-inductively coupled plasma-mass spectrometry to in situ U-Pb zircon geochronology: Chemical Geology, v. 211, p. 47-69.

Johnson, B.G., Strauss, J.V., Toro, J., Benowitz, J.A., Ward, W.P. and Hourigan, J.K., 2016, Detrital geochronology of pre-Mississippian strata in the northeastern Brooks Range, Alaska: Insights into the tectonic evolution of northern Laurentia: Lithosphere, v. 8, no. 6, p. 649-667.

Kunzmann, M., Halverson, G.P., Macdonald, F.A., Hodgskiss, M., Sansjofre, P.D., Schumann, D., Rainbird, R.H., 2014, The early Neoproterozoic Chandindu formation of the Fifteenmile group in the Ogilvie Mountains: Yukon Exploration and Geology 2013, p. 93-107.

Lane, L.S. and Gehrels, G.E., 2014, Detrital zircon lineages of late Neoproterozoic and Cambrian strata, NW Laurentia: Geological Society of America Bulletin, v. 126, no. 3-4, p. 398-414.

Lane, L.S., Gehrels, G.E. and Layer, P.W., 2015, Neruokpuk Formation, northern Yukon: U-Pb detrital zircon and Ar-Ar sample descriptions, geochronology data tables and imagery: Geological Survey of Canada Open File 7733, 24 p.

Lane, L.S., Gehrels, G.E. and Layer, P.W., 2016, Provenance and paleogeography of the Neruokpuk Formation, northwest Laurentia: An integrated synthesis: Geological Society of America Bulletin, v. 128, no. 1-2, p. 239-257.

Leslie, C.D., 2006, Detrital zircon geochronology and rift-related magmatism: Central Mackenzie Mountains, Northwest Territories [M.Sc. thesis]: University of Alberta, $224 \mathrm{p}$.

Mattinson, J.M., 2010, Analysis of the relative decay constants of 235U and 238U by multi-step CA-TIMS measurements of closed-system natural zircon samples: Chemical Geology, v. 275 , no. 3-4, p. 186-198.

Macdonald, F.A. and Cohen, P.A., 2011. The Tatonduk inlier, Alaska-Yukon border, in Arnaud, E., Halverson, G. P., Shields-Zhou, G. eds., The Geological Record of Neoproterozoic Glaciations: Geological Society, London, Memoirs, v. 36, p. 389-396.

Macdonald, F., Halverson, G., Strauss, J., Smith, E., Cox, G., Sperling, E., Roots, C., 2012, Early Neoproterozoic Basin Formation in Yukon, Canada: Implications for the make-up and break-up of Rodinia: Geoscience Canada, v. 39, no. 2, p. 77-100.

Macdonald, F.A., McClelland, W.C., Schrag, D.P. and Macdonald, W.P., 2009, Neoproterozoic glaciation on a carbonate platform margin in Arctic Alaska and the origin of the North Slope subterrane: Geological Society of America Bulletin, v. 121, no. 3-4, p. 448-473.

Macdonald, F.A., Schmitz, M.D., Strauss, J.V., Halverson, G.P., Gibson, T.M., Eyster, A., Cox, G., Mamrol, P. and Crowley, J.L., 2018, Cryogenian of Yukon: Precambrian Research, v. 319, pp.114-143.

McClelland, W.C., Colpron, M., Piepjohn, K., von Gosen, W., Ward, W.P. and Strauss, J.V., 2015, Preliminary detrital zircon geochronology of the Neruokpuk Formation in the Barn Mountains, Yukon: Yukon Exploration and Geology 2014, p. 123-143.

Morrow, D.W., 1989. Lower Paleozoic stratigraphy of the White Mountains, Yukon, and Northwest Territories, and sedimentological evidence for the existence of a "White Mountains platform": Current research, Part G. Geological Survey of Canada, Paper, v. 89, p.77-84. 
Mustard, P.S. and Roots, C.F., 1997, Rift-related volcanism, sedimentation, and tectonic setting of the Mount Harper Group, Ogilvie Mountains, Yukon Territory, Geological Survey of Canada Bulletin, v. 492, 92 p.

Mustard, P.S., Donaldson, J.A., and Thompson, R.I., Trace fossils and stratigraphy of the Precambrian-Cambrian boundary sequence, upper Harper group, Ogilvie Mountains, Yukon, Current Research, Part E, Geological Survey of Canada Paper 88-1E, p. 197-203.

Norris, D.K.,1981, Geology of Bell River map-area, Yukon Territory-Northwest Territories: Geological Survey of Canada, Map 1519A (1:250 000).

Norris, D.K., 1997, The Geology, mineral and hydrocarbon potential of northern Yukon Territory and northwestern District of Mackenzie: Geological Survey of Canada Bulletin, v. 422. $401 \mathrm{p}$.

Paces, J.B. and Miller Jr, J.D., 1993, Precise U-Pb ages of Duluth complex and related mafic intrusions, northeastern Minnesota: Geochronological insights to physical, petrogenetic, paleomagnetic, and tectonomagmatic processes associated with the $1.1 \mathrm{Ga}$ midcontinent rift system: Journal of Geophysical Research: Solid Earth, v. 98, no. B8, p. 13997-14013.

Payne, J.L., Barovich, K.M., and Hand, M., 2006, Provenance of metasedimentary rocks in the northern Gawler Craton, Australia: Implications for Palaeoproterozoic reconstructions: Precambrian Research, v. 148, p. 275-291.

Rainbird, R.H., Rayner, N.M., Hadlari, T., Heaman, L.M., Ielpi, A., Turner, E.C. and MacNaughton, R.B., 2017, Zircon provenance data record the lateral extent of pancontinental, early Neoproterozoic rivers and erosional unroofing history of the Grenville orogen: Geological Society of America Bulletin, v. 129, no. 11-12, p. 14081423.

Saylor, J. E., and Sundell, K. E., 2016, Quantifying comparison of large detrital geochronology data sets: Geosphere, v. 12, no. 1, p. 203-220.

Sláma, J., Košler, J, Condon, D.J., Crowley, J.L., Gerdes, A., Hanchar, J.M., Horstwood, M.S.A., Morris, G.A., Nasdala, L., Norberg, N., Schaltegger, U., Schoene, B., Tubrett, M.N., and Whitehouse, M.J., 2008, Plešovice zircon-A new natural reference material for U-Pb and Hf isotopic microanalysis: Chemical Geology, v. 249, p. 1-35.

Stacey, J.S., and Kramers, J.D., 1975, Approximation of terrestrial lead isotope evolution by a two-stage model: Earth and Planetary Science Letters, v. 26, no. 2, p. 207-221.

Strauss, J.V., Johnson, B.G., Colpron, M., Nelson, L.L., Perez, J.L., Benowitz, J.A., Ward, W.P., McClelland, W.C., 2019a, Pre-Mississippian stratigraphy and provenance of the North Slope subterrane of Arctic Alaska I: Platformal rocks of the northeastern Brooks Range and their significance in circum-Arctic evolution. Circum-Arctic Structural Events: Tectonic Evolution of the Arctic Margins and Trans-Arctic Links with Adjacent Orogens: Geological Society of America Special Paper 541, p 525-572.

Strauss, J.V., MacDonald, F.A., Halverson, G.P., Tosca, N.J., Schrag, D.P. and Knoll, A.H., 2015, Stratigraphic evolution of the Neoproterozoic Callison Lake Formation: Linking the breakup of Rodinia to the Islay carbon isotope excursion: American Journal of Science, v. 315, no. 10, p.881-944.

Strauss, J.V., Macdonald, F.A., McClelland, W.C., Piepjohn, K., McClelland, W.C., Reinhardt, L. and Strauss, J.V., 2019b, Pre-Mississippian stratigraphy and provenance of the North Slope subterrane of Arctic Alaska II: Basinal rocks of the northeastern Brooks Range and their significance in circum-Arctic evolution, in Piepjohn, K., Strauss, J.V., Reinhardt, L., and McClelland, W.C., eds., Circum-Arctic Structural Events: Tectonic Evolution of the Arctic 
Margins and Trans-Arctic Links with Adjacent Orogens: Geological Society of America Special Paper 541, p 493-524.

Strauss, J.V., Macdonald, F.A., Taylor, J.F., Repetski, J.E. and McClelland, W.C., 2013, Laurentian origin for the North Slope of Alaska: Implications for the tectonic evolution of the Arctic: Lithosphere, v. 5, no. 5, p. 477-482.

Taylor, J.F., Allen, T.J., Repetski, J.E., Strauss, J.V., and Irwin, S.J., 2015, Life on the edge in eastern Alaska: basal Ordovician (Tremadocian) platform-margin faunas of the Jones Ridge Limestone, in S.A. Leslie, D. Goldman, and R.C. Orndorff, eds., 12th International Symposium on the Ordovician System, Short Papers and Abstracts: Stratigraphy, v. 12, no. 2, p. 70-77.

Turner, E.C., 2011. Stratigraphy of the Mackenzie Mountains supergroup in the Wernecke Mountains, Yukon: Yukon Exploration and Geology 2010, p. 207-231.

Watson, E.B., Wark, D.A., and Thomas, J.B., 2006, Crystallization thermometers for zircon and rutile: Contributions to Mineralogy and Petrology, v. 151, p. 413-433.

Wilson, F.H., Hults, C.P., Mull, C.G., and Karl, S.M, 2015, Geological Map of Alaska, U.S. Geological Survey Scientific Investigations Map 3340, pamphlet 196 p., 2 sheets, scale $1: 1,584,000$

Young, G.M., 1982. The late Proterozoic Tindir Group, east-central Alaska: Evolution of a continental margin: Geological Society of America Bulletin, v. 93, no. 8, p.759-783.

SUPPLEMENTAL DATA TABLES 
TABLE S1: SUMMARY OF NEW AND COMPILED DETRITAL ZIRCON GEOCHRONOLOGY SAMPLES USED IN THIS STUDY

\begin{tabular}{|c|c|c|c|c|c|c|c|c|c|}
\hline Sample & IGSN & Map unit & Latitude $^{\circ}$ & Longitude $^{\circ}$ & Age & Location & Tectonic Element & $n$ & Source \\
\hline J1009-435 & IEJVS0001 & Jones Ridge Fm & 65.1105500 & -141.0174167 & Cambrian & Tatonduk inlier & $\mathrm{Yb}$ & 87 & This Study \\
\hline J1122-118 & IEJVS0002 & Slats Creek Fm & 64.6194444 & -136.9266389 & Cambrian & Hart River inlier & $\mathrm{Yb}$ & 61 & This Study \\
\hline J1212 & IEJVS0003 & Illtyd Fm & 65.1021944 & -134.6882500 & Cambrian & Illtyd Range & $\mathrm{Yb}$ & 91 & This Study \\
\hline J1357A & IEJVS0004 & Illtyd Fm & 67.9706389 & -136.7648056 & Cambrian & White Uplift & $\mathrm{Yb}$ & 93 & This Study \\
\hline J1708-104.9 & IEJVS0005 & Shell Creek Fm & 64.7914200 & -140.1444780 & Cambrian & Coal Creek inlier & $\mathrm{Yb}$ & 279 & This Study \\
\hline J1714 & IEJVS0006 & Shell Creek Fm & 64.7434760 & -140.1287480 & Cambrian & Coal Creek inlier & $\mathrm{Yb}$ & 280 & This Study \\
\hline F921-6 & IEJVS0007 & Last Chance Fm & 64.7810333 & -140.0642333 & Ediacaran & Coal Creek inlier & $\mathrm{Yb}$ & 151 & This Study \\
\hline J1119 & IEJVS0008 & Tindir Gp & 65.0223611 & -141.1395833 & Ediacaran & Tatonduk inlier & $\mathrm{Yb}$ & 96 & This Study \\
\hline S1601 & IEJVS0009 & Map Unit Pu & 67.9800000 & -136.7600000 & Ediacaran & White Uplift & $\mathrm{Yb}$ & 282 & This Study \\
\hline W7 (F850-214) & IEJVSO00A & Gametrail Fm & 64.8731667 & -133.0078833 & Ediacaran & Wernecke inlier & $\mathrm{Yb}$ & 83 & This Study \\
\hline 13WW29 & IEJVSO00B & Map Unit Pu & 67.9927770 & -136.7557220 & Cryogenian & White Uplift & $\mathrm{Yb}$ & 200 & This Study \\
\hline J1601 & IEJVSO00C & Map Unit Pu & 67.9927770 & -136.7557220 & Cryogenian & White Uplift & $\mathrm{Yb}$ & 312 & This Study \\
\hline F842-35.5 & IEJVSO0OD & Eagle Creek Fm & 64.6929167 & -140.1130167 & Cryogenian & Coal Creek inlier & $\mathrm{Yb}$ & 60 & This Study \\
\hline F1223 & IEJVSO00E & Twitya Fm & 64.7666667 & -133.0500000 & Cryogenian & Wernecke inlier & $\mathrm{Yb}$ & 71 & This Study \\
\hline F845-82 & IEJVSOOOF & Fifteenmile Gp & 65.2638667 & -140.9710833 & Tonian & Tatonduk inlier & $\mathrm{Yb}$ & 84 & This Study \\
\hline J1404 & IEJVSOOOH & Fifteenmile Gp & 65.2654833 & -140.9429667 & Tonian & Tatonduk inlier & $\mathrm{Yb}$ & 277 & This Study \\
\hline G0117-45.5 & IEJVSO00G & Fifteenmile Gp & 65.2544330 & -133.9535830 & Tonian & Tatonduk inlier & $\mathrm{Yb}$ & 85 & This Study \\
\hline J1019-45.1 & IEJVSOOOI & Callison Lake Fm & 64.6886000 & -139.3528167 & Tonian & Coal Creek inlier & $\mathrm{Yb}$ & 79 & This Study \\
\hline J1208 & IEJVS000J & Chandindu Fm & 64.7839167 & -139.6691667 & Tonian & Coal Creek inlier & $\mathrm{Yb}$ & 82 & This Study \\
\hline M104 & IEJVSO00K & Tarn Lake Fm & 64.7714167 & -133.1081667 & Tonian & Wernecke inlier & $\mathrm{Yb}$ & 85 & This Study \\
\hline M201b & IEJVSO0OL & Fifteenmile Gp & 64.7540556 & -139.9387222 & Tonian & Coal Creek inlier & $\mathrm{Yb}$ & 112 & This Study \\
\hline M201c & IEJVSOOOM & Fifteenmile Gp & 64.7540556 & -139.9387222 & Tonian & Coal Creek inlier & $\mathrm{Yb}$ & 59 & This Study \\
\hline 07CL-1442A & - & Abraham Plains Fm & - & - & Tonian & Mackenzie Mtns & $\mathrm{Mp}$ & 41 & Leslie, 2009 \\
\hline RAS06-188A & - & Little Dal Gp & - & - & Tonian & Mackenzie Mtns & $\mathrm{Mp}$ & 63 & Leslie, 2009 \\
\hline 07CL-1553A & - & Backbone Ranges Fm & - & - & Cambrian & Mackenzie Mtns & $\mathrm{Mp}$ & 63 & Leslie, 2009 \\
\hline CL06-44A & - & Sekwi Fm & - & - & Cambrian & Mackenzie Mtns & $\mathrm{Mp}$ & 68 & Leslie, 2009 \\
\hline EM06-113B & - & Franklin Mountain Fm & - & - & Cambrian & Mackenzie Mtns & $\mathrm{Mp}$ & 49 & Leslie, 2009 \\
\hline CL06-47A & - & Backbone Ranges Fm & - & - & Ediacaran & Mackenzie Mtns & $\mathrm{Mp}$ & 52 & Leslie, 2009 \\
\hline CL06-48A & - & Keele Fm & - & - & Cryogenian & Mackenzie Mtns & $\mathrm{Mp}$ & 57 & Leslie, 2009 \\
\hline 07-LG-14-A (B) & - & Saline River Fm & - & - & Cambrian & Mackenzie Mtns & $\mathrm{Mp}$ & 95 & Hadlari et al., 2012 \\
\hline 07-YHL-44-A (A) & - & Saline River Fm & - & - & Cambrian & Mackenzie Mtns & $\mathrm{Mp}$ & 108 & Hadlari et al., 2012 \\
\hline 88PF-5 & - & Illtyd Fm & - & - & Cambrian & Mackenzie Mtns & $\mathrm{Mp}$ & 88 & Lane and Gehrels, 2014 \\
\hline HHP72-72 & - & Slats Creek Fm & - & - & Cambrian & Mackenzie Mtns & Mp & 91 & Lane and Gehrels, 2014 \\
\hline 1103NC-1 & - & Keele Fm & - & - & Cryogenian & Mackenzie Mtns & Mp & 97 & Lane and Gehrels, 2014 \\
\hline 1105NC-4 & - & Rapitan Gp & - & - & Cryogenian & Mackenzie Mtns & $\mathrm{Mp}$ & 91 & Lane and Gehrels, 2014 \\
\hline 11-MWB-128 & - & Tsezotene Fm & - & - & Tonian & Mackenzie Mtns & $\mathrm{Mp}$ & 59 & Rainbird et al., 2017 \\
\hline 11-MWB-129 & - & Grafe River Fm & - & - & Tonian & Mackenzie Mtns & $\mathrm{Mp}$ & 98 & Rainbird et al., 2017 \\
\hline 11-MWB-130 & - & Shattered Range Fm & - & - & Tonian & Mackenzie Mtns & $\mathrm{Mp}$ & 90 & Rainbird et al., 2017 \\
\hline 11-MWB-131 & - & Abraham Plains Fm & - & - & Tonian & Mackenzie Mtns & $\mathrm{Mp}$ & 107 & Rainbird et al., 2017 \\
\hline 95-14 & - & Mount Weller Gp & - & - & Tonian & Sadlerochit Mtns & NSs & 112 & Macdonald et al., 2009; Strauss et al., 2019a \\
\hline 95-15 & - & Mount Weller Gp & - & - & Tonian & Sadlerochit Mtns & NSs & 96 & Macdonald et al., 2009; Strauss et al., 2019a \\
\hline F608 & - & Hula Hula diamictite & - & - & Cryogenian & Sadlerochit Mtns & NSs & 101 & Macdonald et al., 2009; Strauss et al., 2019a \\
\hline F1143 & - & Mount Weller Gp & - & - & Tonian & Sadlerochit Mtns & NSs & 82 & Strauss et al., 2013; Strauss et al., 2019a \\
\hline F1145 & - & Mount Weller Gp & - & - & Tonian & Sadlerochit Mtns & NSs & 77 & Strauss et al., 2013; Strauss et al., 2019a \\
\hline F1147 & - & Redwacke Creek Fm & - & - & Ediacaran & British Mtns & NSs & 86 & Strauss et al., 2013; Strauss et al., 2019a \\
\hline F1150 & - & Neruokpuk Fm & - & - & Cambrian & British Mtns & NSs & 94 & Strauss et al., 2013; Strauss et al., 2019a \\
\hline J1111 & - & Malcolm River Fm & - & - & Cambrian & British Mtns & NSs & 92 & Strauss et al., 2013; Strauss et al., 2019a \\
\hline J1115 & - & Fish Creek Fm & - & - & Ediacaran & British Mtns & NSs & 81 & Strauss et al., 2013 \\
\hline 13-007 & - & Neruokpuk Fm & - & - & Cambrian & Barn Mtns & NSs & 80 & McClelland et al., 2015 \\
\hline 13-016 & - & Neruokpuk Fm & - & - & Cambrian & Barn Mtns & NSs & 84 & McClelland et al., 2015 \\
\hline 13-018 & - & Neruokpuk Fm & - & - & Cambrian & Barn Mtns & NSs & 84 & McClelland et al., 2015 \\
\hline 87LHA27-5 & - & Neruokpuk Fm & - & - & Cambrian & British Mtns & NSs & 81 & Lane et al., 2015; 2016 \\
\hline 94LHA10-7A & - & Neruokpuk Fm & - & - & Cambrian & British Mtns & NSs & 98 & Lane et al., 2015; 2016 \\
\hline 94LHA14-3 & - & Neruokpuk Fm & - & - & Cambrian & British Mtns & NSs & 99 & Lane et al., 2015; 2016 \\
\hline 12JT31 & - & Firth River Gp & - & - & Ediacaran & British Mtns & NSs & 75 & Johnson et al., 2016 \\
\hline $05 \mathrm{LF} 13$ & - & Neruokpuk Fm & - & - & Cambrian & British Mtns & NSs & 82 & Johnson et al., 2016 \\
\hline $11 \mathrm{LF} 13$ & - & Neruokpuk Fm & - & - & Cambrian & British Mtns & NSs & 85 & Johnson et al., 2016 \\
\hline 12JT10 & - & Neruokpuk Fm & - & - & Cambrian & British Mtns & NSs & 83 & Johnson et al., 2016 \\
\hline 12JT11 & - & Neruokpuk Fm & - & - & Cambrian & British Mtns & NSs & 81 & Johnson et al., 2016 \\
\hline 12JT32 & - & Neruokpuk Fm & - & - & Cambrian & British Mtns & NSs & 51 & Johnson et al., 2016 \\
\hline J1107 & - & Mount Weller Gp & - & - & Tonian & Shublik Mtns & NSs & 84 & Strauss et al., 2019a \\
\hline J1334 & - & Fish Creek Fm & - & - & Ediacaran & British Mtns & NSs & 91 & Strauss et al., 2019a \\
\hline 08ACH018 & - & Neruokpuk Fm & - & - & Cambrian & British Mtns & NSs & 96 & Strauss et al., 2019a \\
\hline J1327 & - & Neruokpuk Fm & - & - & Cambrian & British Mtns & NSs & 88 & Strauss et al., 2019a \\
\hline J1349 & - & Neruokpuk Fm & - & - & Cambrian & British Mtns & NSs & 91 & Strauss et al., 2019a \\
\hline J1470 & - & Neruokpuk Fm & - & - & Cambrian & British Mtns & NSs & 255 & Strauss et al., 2019a \\
\hline 13-083 & - & Firth River Gp & - & - & Ediacaran & British Mtns & NSs & 261 & Colpron et al., 2019 \\
\hline 13-116 & - & Firth River Gp & - & - & Ediacaran & British Mtns & NSs & 268 & Colpron et al., 2019 \\
\hline 13-131 & - & Barn Gp & - & - & Cambrian & Barn Mtns & NSs & 265 & Colpron et al., 2019 \\
\hline $13-139$ & - & Leffingwell Fm & - & - & Cambrian & British Mtns & NSs & 295 & Colpron et al., 2019 \\
\hline
\end{tabular}

IGSN - International Geo Sample Number; n-sample size; Fm -Formation; Gp-Group; Mtns-Mountains; Yb-Yukon block; Mp-Mackenzie platform; NSs - North Slope subterrane.

Table S2. New detrital zircon U-Pb geochronological data published in this study. See accompanying .xlsx file.

Table S3. Complete detrital zircon U-Pb age dataset used for statistical analyses from this study. See accompanying .xlsx file. 